\title{
Catfish Special Issue: Growth of Non-0157:H7 Shiga-Toxin Producing Escherichia Coli on Catfish Fillets
}

\author{
Parvaneh Khosravi ${ }^{1}$, Juan Silva ${ }^{1}$, Christopher H. Sommers ${ }^{2 *}$ and Shiowshuh Sheen ${ }^{2}$
}

${ }^{1}$ Mississippi State University, Food Processing and Safety, Department of Food Science, Nutrition, and Health Promotion, Mississippi State, MS, USA ${ }^{2}$ Eastern Regional Research Center, U.S. Department of Agriculture, Agricultural Research Service, Wyndmoor, Pennsylvania, USA

\begin{abstract}
Shiga-toxin producing Escherichia coli (STECs) are emerging pathogens which have been involved in numerous foodborne illness outbreaks. In this study the ability of a multi-isolate cocktail of STEC serovars O26: $\mathrm{H} 11, \mathrm{O} 45: \mathrm{H} 2$, 0103:H2, O111: NM, O121: $\mathrm{H} 19$, and O145:RM to grow on catfish fillets at refrigeration and abuse temperatures was investigated. Catfish fillet samples $(10 \mathrm{~g})$ were inoculated with the STEC cocktails to ca. $3 \mathrm{log}$ CFU/g and incubated under aerobic conditions for up to $120 \mathrm{hrs}$. There was no STEC growth at $4^{\circ} \mathrm{C}$, however, the STECs grew at $10,15,20$ and $30^{\circ} \mathrm{C}$ in a temperature dependent manner, with higher growth rate being associated with higher temperature. Lag phase ranged from $15 \mathrm{~h}$ at $10^{\circ} \mathrm{C}$ to $1.75 \mathrm{~h}$ at $30^{\circ} \mathrm{C}$. Exponential phase growth rate ranged from $0.03 \log \mathrm{CFU} / \mathrm{g} / \mathrm{h}$ at $10^{\circ} \mathrm{C}$ to $0.65 \mathrm{log} \mathrm{CFU} / \mathrm{g} / \mathrm{h}$ at $30^{\circ} \mathrm{C}$. Growth curves constructed using ComBase DMfit provided a good statistical fit to the observed data, resulting in a high correlation coefficient $\left(R^{2}\right)$ of 0.98 . The results of this study provide information to risk assessors regarding the growth potential of the STECs on aquaculture-raised fish using catfish as a model system.
\end{abstract}

Keywords: E coli; STEC; Catfish; Growth curves

\section{Introduction}

There is growing public concern about the microbial safety of foods today. Foodborne pathogens are significant public health hazards in the United States [1-2]. Seafood has received increasing attention as a vehicle for foodborne illness in the United States. When adjusted for the annual per capita consumption of ca. $17 \mathrm{lbs}$, it is responsible for more foodborne illnesses than other meats or produce [3-6].

Shiga toxin-producing Escherichia coli (STEC) are a group of foodborne pathogens that have caused outbreaks and sporadic cases of human infections worldwide [7-11]. Although many foodborne infections are due to E. coli O157:H7, non-O157 STEC are also important pathogens and can cause human illnesses and lifethreatening hemolytic uremic syndrome. Six non-O157 serogroups (O26, O45, O103, O111, O121, and O145) now account for the majority of reported non-O157 STEC infections [10]. The emerging clinical importance of non-O157 STEC has been evaluated [11] and results conclude that these strains may account for $20-50 \%$ of all STEC infections in the United States $[1,2,10]$.

Aquaculture now accounts for ca. $50 \%$ of seafood production worldwide [12]. Contamination of seafood (either wild caught or aquaculture-raised) with pathogenic $E$. coli has been known to occur, much of which is due to contaminated water sources, in many parts of the world [13-21]. In contrast, illnesses due to STECs from consumption of farm raised catfish in the U.S. are extremely rare [21-23]. While studies have examined the growth potential of $E$. coli O157:H7 and non-O157 STECs in meat [23], very little information is available on the growth potential of STEC in aquaculture-grown seafood products. Because we live in a global trade environment, which includes import and export of seafood products, it would be prudent to assess the growth potential of the STECs in seafood products.

The objective of this study was to evaluate the growth of a multiisolate cocktail of non-O157:H7 STECs (serovars O26, O45, O103, O111, O121, and O145), using catfish fillets (Ictalurus punctatus) under refrigeration and temperature-abuse conditions as a model system for aquaculture-raised finfish.

\section{Materials and Methods}

\section{Bacterial strains}

Six shiga-toxin producing Escherichia coli isolates representing serotypes O26: H11, O45: H2, O103: H2, O111: H11, O121: H19, and O145: RM were obtained from Dr. Rob Mandrell (USDA, WRRC Albany, CA) via Dr. Pina Fratamico (USDA, ERRC, Wyndmoor, PA). The STECs were propagated on Brain Heart Infusion Agar (BHA, BBL/ Difco Laboratories, Sparks, MD) and stored at $4^{\circ} \mathrm{C}$ prior to use.

\section{Catfish fillets}

Refrigerated (never frozen) catfish fillets (30 lbs of $84 \mathrm{~g}$ fillets, no additives) were obtained in bulk from a Mississippi-based catfish processor and shipped overnight to the Eastern Regional Research Center. The fillets were then subdivided and frozen at $-20^{\circ} \mathrm{C}$ in sealed polynylon bags (Uline, Inc., Philadelphia, PA). Naturally occurring $E$. coli was $<0.1 \mathrm{CFU} / \mathrm{g}$ (undetectable) which was determined using E.coli PetriFilms ${ }^{\mathrm{TM}}$ as described below. Background microflora $\left(22\right.$ and $\left.37^{\circ} \mathrm{C}\right)$ determined using Aerobic Plate Count PetriFilms were approximately $10^{4}-10^{5} \mathrm{CFU} / \mathrm{g}$. The catfish was allowed to thaw overnight in a refrigerator at $4^{\circ} \mathrm{C}$ prior to use in growth experiments.

\section{Bacterial growth and inoculation}

The procedure for inoculation and enumeration of bacteria was performed as previously described [24]. Each bacterial strain was

${ }^{*}$ Corresponding author: Christopher $\mathrm{H}$. Sommers, Food Safety and Intervention Technologies Research Unit, Eastern Regional Research Center, USDA-ARS, 600 East Mermaid Lane, Wyndmoor, PA 19038, Tel: 215-836-3754; FAX: 215-2336445; E-mail: Christopher.sommers@.ars.usda.gov

Received January 25, 2013; Accepted January 27, 2013; Published February 05, 2013

Citation: Khosravi P, Silva J, Sommers CH, Sheen S (2013) Catfish Special Issue: Growth of Non-O157:H7 Shiga-Toxin Producing Escherichia Coli on Catfish Fillets. J Food Process Technol S11-004. doi:10.4172/2157-7110.S11-004

Copyright: (C) 2013 Khosravi P, et al. This is an open-access article distributed under the terms of the Creative Commons Attribution License, which permits unrestricted use, distribution, and reproduction in any medium, provided the original author and source are credited. 
cultured independently in $10 \mathrm{~mL}$ of Brain Heart Infusion Broth (BHIB, $\mathrm{BBL} /$ Difco Laboratories, Sparks, $\mathrm{MD}$ ) in sterile $50 \mathrm{~mL}$ polypropylene tubes at $37^{\circ} \mathrm{C}(150 \mathrm{rpm})$ for 18 to $24 \mathrm{~h}$. The STEC isolates grew to a cell density of ca. $10^{9} \mathrm{CFU} / \mathrm{mL}$. The cultures were then combined, mixed by vortexing, and diluted in sterile $0.1 \%$ peptone water (PW-BBL/ Difco Laboratories, Sparks, MD). The use of multi-isolate cocktails is recommended per the NACMCF [25]. The diluted STEC cocktail was then inoculated $(0.1 \mathrm{~mL})$ onto $10 \mathrm{~g}$ catfish fillet pieces to obtain a STEC density of ca. $10^{3} \mathrm{CFU} / \mathrm{g}$. Three replicate samples were prepared for each time temperature condition. The samples were placed in sterile polynylon sample bags (Uline, Inc., Philadelphia, PA), which were then sealed and placed at the appropriate incubation temperatures $(4,10,15$, $23,30^{\circ} \mathrm{C}$ ), without ice.

\section{Enumeration of bacteria}

Following storage, the samples were assayed for surviving bacteria by standard microbiological procedures. Ninety $\mathrm{mL}$ of sterile $\mathrm{PW}$ was added to sample bags with $10 \mathrm{~g}$ of inoculated sample, mixed by stomaching for $90 \mathrm{~s}$ (Stomacher Mixer, Seward Co., UK). The samples were then serially diluted in PW, using tenfold dilutions, and $1 \mathrm{~mL}$ of diluted sample was placed onto duplicate E. coli PetriFilms ${ }^{\mathrm{TM}}(3 \mathrm{M}$, Minneapolis, MN).The Petrifilms ${ }^{\mathrm{TM}}$ were then incubated ca. $24 \mathrm{hrs}$ prior to enumeration. Non-inoculated samples were prepared and stored at the various storage temperatures, and no E. coli were detected on the PetriFilms ${ }^{\mathrm{TM}}$.

\section{Statistical analysis}

Each experiment was conducted independently twice with 3 replicates per experiment. Combase DMfit software (http://www. combase.cc/index.php/en/) was used to fit the observed data at all temperatures and determine the lag time, growth rate, maximum population and of the STECs on catfish fillets (Table 1) using the Baranyi and Roberts model [26-30]. Descriptive statistics, variance and graphics were completed using Microsoft Excel Office 2003 (Microsoft Corp., Redmond, WA).

\section{Results and Discussion}

Although not an issue in the U.S. [22], foodborne illnesess from seafood contaminated with STECs are a significant problem in many areas of the world [13-21]. To date there are few tools available to predict the risk of STEC growth in seafood as a result of either mild or severe temperature abuse. The purpose of this study was to determine the growth potential of non-O157:H7 STECs stored aerobically under various temperatures using catfish as a model system. In the current, study background microflora grew to a density of $>7 \mathrm{log} \mathrm{CFU} / \mathrm{g}$ in non-inoculated samples within three days, regardless of storage temperature. The STECs were capable of growth in the presence of background microflora at all temperatures with the exception of $4^{\circ} \mathrm{C}$ (Table 1).

Catfish fillets inoculated with ca. $3 \log \mathrm{CFU} / \mathrm{g}$ of STEC and incubated at temperatures from $4-30^{\circ} \mathrm{C}$ began to show growth at different lag phases and growth rates (Table 1 and Figures 1-5). ComBase DMfit was used to fit observed data and determine lag time, growth rate, and maximum population of the STECs on catfish fillets (Table 1). The growth curves constructed using DMFit show a good fit with the observed data $\left(\mathrm{R}^{2} \geq 0.98\right)$ using the model of Baranyi and Roberts [30].

According to our observations the non-O157:H7 STECs did not grow at $4^{\circ} \mathrm{C}$ (Figure 1). The growth potential was depressed at $4^{\circ} \mathrm{C}$, as the cell population decreased about $0.3-0.5 \log \mathrm{CFU} / \mathrm{g}$. This data is in agreement with that obtained in other studies which evaluated the growth potential of non-O157:H7 STECs in ground beef [25].

At $10^{\circ} \mathrm{C}$ the STEC growth in catfish fillets was less than $1 \log \mathrm{CFU} / \mathrm{g}$ (0.29 $\log \mathrm{CFU} / \mathrm{g}$ ) for up to $24 \mathrm{~h}$ after the initial inoculation, with a lag phase of $15.0 \mathrm{~h}$ (Table 1). After $24 \mathrm{~h}$, growth increased exponentially, growth rate of $0.03 \log \mathrm{CFU} / \mathrm{g}$ ), with no additional growth at $96 \mathrm{~h}$ and

\begin{tabular}{|c|c|c|c|c|c|}
\hline $\begin{array}{c}\text { Temperature } \\
\left({ }^{\circ} \mathbf{C}\right)\end{array}$ & $\begin{array}{c}\text { Initial value } \\
\text { (log CFU/g) }\end{array}$ & $\begin{array}{c}\text { Lag phase } \\
\text { (hr) }\end{array}$ & $\begin{array}{c}\text { Maximum rate } \\
\text { (log CFU/g/hr) }\end{array}$ & $\begin{array}{c}\text { Final value } \\
\text { (log CFU/g) }\end{array}$ & R-square \\
\hline 4 & ND & ND & ND & ND & ND \\
\hline 10 & 3.76 & 15.0 & 0.03 & 6.59 & 0.98 \\
\hline 15 & 3.51 & 11.7 & 0.34 & 8.57 & 0.99 \\
\hline 22 & 3.51 & 4.63 & 0.34 & 9.91 & 0.99 \\
\hline 30 & 4.04 & 1.75 & 0.65 & 10.1 & 0.99 \\
\hline
\end{tabular}

Lag phase, exponential phase growth rates, stationary phase times were determined using DMFit software available through ComBase. ND $=$ Not determined due to lack of growth.

Table 1: Estimated maximum growth rate, lag time and maximum population of non-O157:H7 Shiga-toxin producing Escherichia coli inoculated on catfish fillets at different temperatures

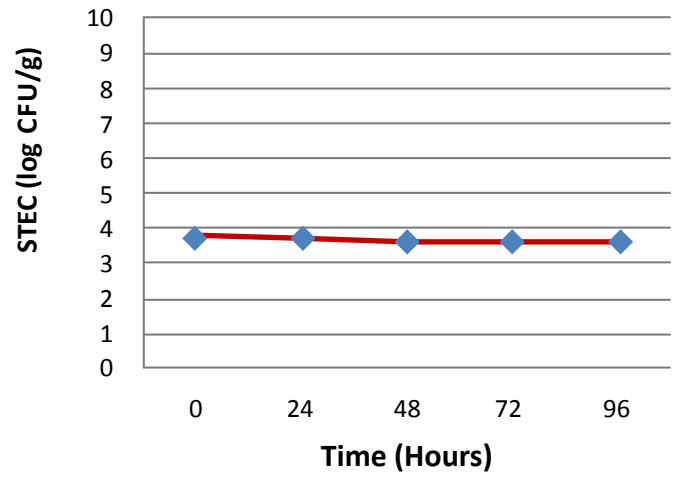

Figure 1: Growth data for Shiga-toxin producing Escherichia coli (STEC) on catfish at $4^{\circ} \mathrm{C}$ storage. Each experiment was conducted twice $(n=2)$. Mean log $\mathrm{CFU} / \mathrm{g}$ values are shown as triangles for each time point, and the standard deviation of the mean is shown using error bars.

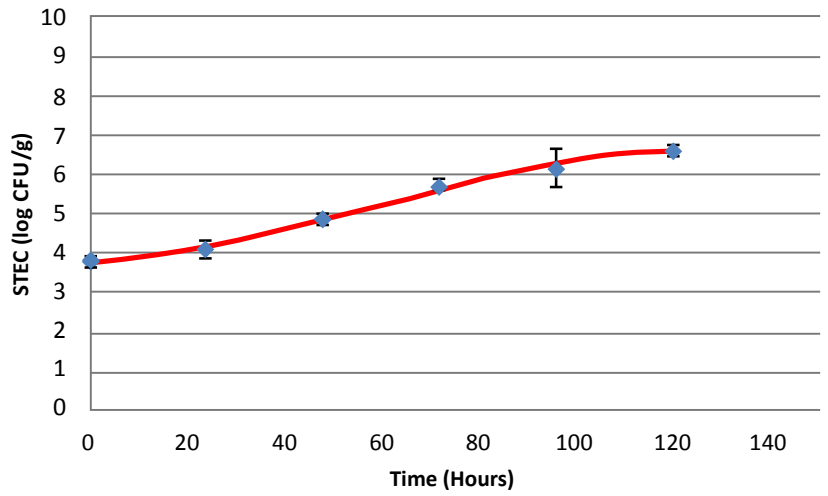

Figure 2: Growth data and predictive model for Shiga-toxin producing Escherichia coli (STEC) on catfish at $10^{\circ} \mathrm{C}$ storage. Each experiment was conducted twice $(n=2)$. Mean log CFU/g values are shown as triangles for each time point, and the standard deviation of the mean is shown using error bars. Growth curves generated using DMFit are shown as solid lines. 


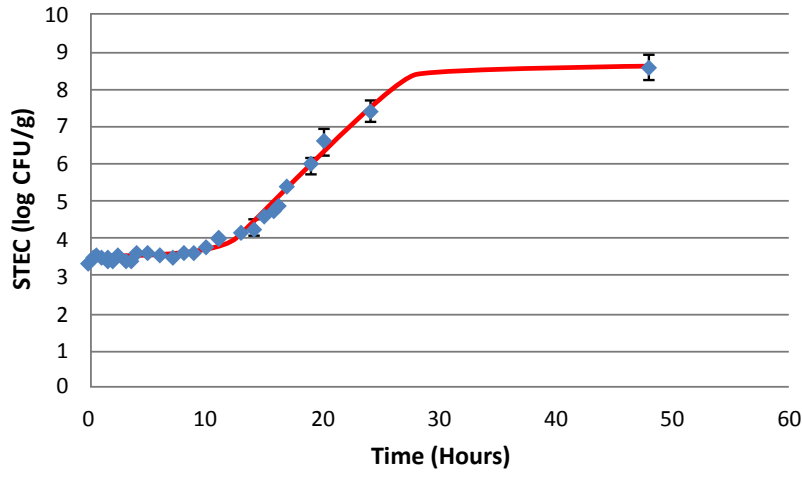

Figure 3: Growth data and predictive model for Shiga-toxin producing Escherichia coli (STEC) on catfish at $15^{\circ} \mathrm{C}$ storage. Each experiment was conducted twice $(n=2)$. Mean log CFU/g values are shown as triangles for each time point, and the standard deviation of the mean is shown using error bars. Growth curves generated using DMFit are shown as solid lines.

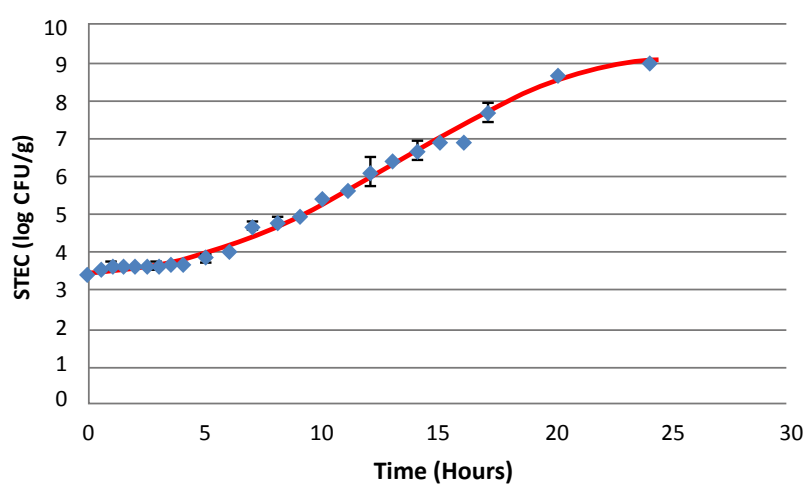

Figure 4: Growth data and predictive model for Shiga-toxin producing Escherichia coli (STEC) on catfish at $22^{\circ} \mathrm{C}$ storage. Each experiment was conducted twice $(n=2)$. Mean log CFU/g values are shown as triangles for each time point, and the standard deviation of the mean is shown using error bars. Growth curves generated using DMFit are shown as solid lines.

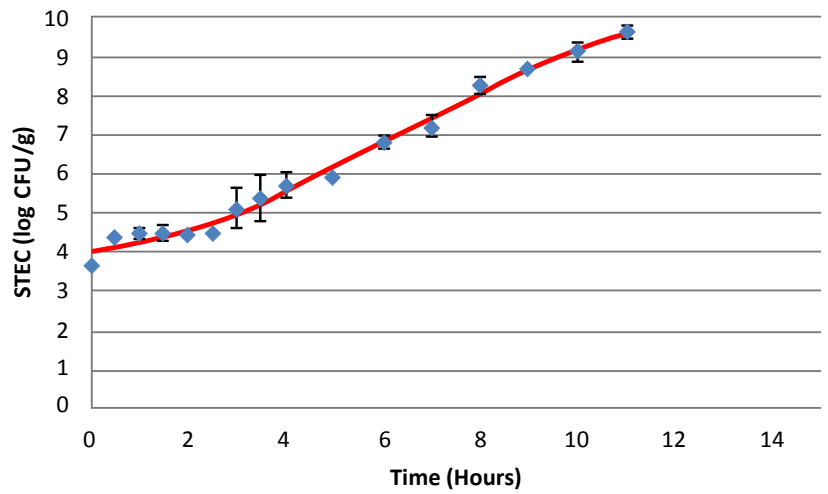

Figure 5: Growth data and predictive model for Shiga-toxin producing Escherichia coli (STEC) on catfish at $30^{\circ} \mathrm{C}$ storage. Each experiment was conducted twice $(n=2)$. Mean log CFU/g values are shown as triangles for each time point, and the standard deviation of the mean is shown using error bars. Growth curves generated using DMFit are shown as solid lines.
$120 \mathrm{~h}$ of incubation (stationary phase) (Figure 2). A previous study conducted using ground beef as the food matrix indicated the nonO157:H7 STECs were unable to grow in the presence of background microflora at $10^{\circ} \mathrm{C}$ [25]. Another study which investigated the growth potential of $E$. coli O157:H7 in ground beef reported the lag phase as $56.3 \mathrm{~h}$ and the exponential growth rate as $0.05 \mathrm{CFU} / \mathrm{g} / \mathrm{h}$. In contrast, E. coli $\mathrm{O} 157: \mathrm{H} 7$ has been demonstrated to grow at $10^{\circ} \mathrm{C}$ on lettuce, with an estimated lag time of $32.5 \mathrm{hrs}$ prior to the start of exponential growth and an exponential growth rate of $0.02 \mathrm{CFU} / \mathrm{g} / \mathrm{h}$ [26].

The non-O157:H7 STECs grew faster when temperature increased as determined by the observed data and fitted growth curves generated by DMfit (Figures 3-5). Except for the lowest temperature at $4^{\circ} \mathrm{C}$, STEC at all temperatures, and all fitted curves exhibited lag, exponential and partially stationary phases (Figures 2-5). Lag phase decreased from $15.0 \mathrm{~h}$ at $10^{\circ} \mathrm{C}$ to $1.75 \mathrm{~h}$ at $30^{\circ} \mathrm{C}$. Growth rate in the exponential phase increased from 0.03 at $10^{\circ} \mathrm{C}$ to $0.65 \mathrm{CFU} / \mathrm{g} / \mathrm{h}$ at $30^{\circ} \mathrm{C}$ (Table 1 ).

\section{Conclusions}

Catfish fillets are a relatively short shelf-life product, even under refrigeration conditions. The non-O157:H7 STECs did not grow under proper refrigeration conditions, but were capable of growth in the presence of background microflora at a mild abuse temperature of $10^{\circ} \mathrm{C}$, with a lag time significantly shorter than those for STECs on lettuce [26] and ground beef [25]. The results confirm that the growth behavior of foodborne pathogen is food matrix dependent. This information will help the seafood industry and risk assessors provide safer seafood products to consumers and guidance to the freshwater fish processing industry. These results highlight the hazards of STEC growth under conditions of mild temperature abuse in developed countries, and more severe temperature abuse which can occur in developing countries with limited refrigeration capability.

\section{References}

1. Scallan E, Hoekstra RM, Angulo FJ, Tauxe RV, Widdowson MA, et al. (2011) Foodborne illness acquired in the United States-major pathogens. Emerg Infect Dis 17: 7-15

2. Scharff RL (2010) Health-Related Costs from Foodborne Illness in the United States. Produce Safety Project at Georgetown University.

3. Anonymous (2008) Fish and shellfish cause most foodborne illness outbreaksCSPI. Food Production Daily.

4. Allhouse JE, Buzby JC, Harvey DJ, Zorn D (2004) Seafood safety and trade. USDA-Economic Research Service. Issues in Diet, Safety, and Health Agriculture Information Bulletin Number 789-7

5. Butt AA, Aldridge KE, Sanders CV (2004) Infections related to the ingestion of seafood Part I: Viral and bacterial infections. Lancet Infect Dis 4: 201-212.

6. Lipp EK, Rose JB (1997) The role of seafood in foodborne diseases in the United States of America. Rev Sci Tech 16: 620-640.

7. Doyle MP (1991) Escherichia coli O157:H7 and its significance in foods. Int Food Microbiol 12: 289-301.

8. Brooks JT, Sowers EG, Wells JG, Greene KD, Griffin PM, et al. (2005) Non-O157 Shiga toxin-producing Escherichia coli infections in the United States, 1983-2002. J Infect Dis 192: 1422-1429.

9. Gyles CL (2007) Shiga toxin-producing Escherichia coli: an overview. J Anim Sci 85: E45-E62.

10. Centers for Disease Control and Prevention (CDC) (2011) Vital signs: incidence and trends of infection with pathogens transmitted commonly through food-foodborne diseases active surveillance network, 10 U.S. sites, 1996-2010. MMWR Morb Mortal Wkly Rep 60: 749-755.

11. Johnson KE, Thorpe CM, Sears CL (2006) The emerging clinical importance of non-O157 Shiga toxin-producing Escherichia coli. Clin Infect Dis 43: 15871595. 
Citation: Khosravi P, Silva J, Sommers CH, Sheen S (2013) Catfish Special Issue: Growth of Non-O157:H7 Shiga-Toxin Producing Escherichia Coli on Catfish Fillets. J Food Process Technol S11-004. doi:10.4172/2157-7110.S11-004

12. VanVorhees D (2009) Fisheries of the United States-2008. National Marine Fisheries Service Office of Science and Technology. Pritchard, E. (Ed.). 118p.

13. Wan Norhana M, Poole S, Deeth H, Dykes G (2010) Prevalence, persistence, and control of Salmonella and Listeria in shrimp and shrimp products: A review. Food Control 21: 343-361.

14. Van TT, Chin J, Chapman T, Tran LT, Coloe PJ (2008) Safety of raw meat and shellfish in Vietnam: an analysis of Escherichia coli isolations for antibiotic resistance and virulence genes. Int J Food Microbiol 124: 217-223.

15. Chomvarin $\mathrm{C}$, Ratchtrachenchai $\mathrm{OA}$, Chantarasuk $\mathrm{Y}$, Srigulbutr $\mathrm{S}$, Chaicumpar $\mathrm{K}$, et al. (2005) Characterization of diarrheagenic Escherichia coli isolated from food in Khon Kaen, Thailand. Southeast Asian J Trop Med Public Health 36: 931-939.

16. Manna SK, Das R, Manna C (2008) Microbiological quality of finfish and shellfish with special reference to shiga toxin-producing Escherichia coli 0157. J Food Sci 73: M283-M286.

17. Thampuran N, Surendraraj A, Surendran PK (2005) Prevalence and characterization of typical and atypical Escherichia coli from fish sold at retail in Cochin, India. J Food Prot 68: 2208-2211.

18. Simiyu KW, Gathura PB, Kyule MN, Kanja LW, Ombui JN (1998) Toxin production and antimicrobial resistance of Escherichia coli river water isolates. East Afr Med J 75: 699-702.

19. Teophilo GN, dos Fernandes Vieira RH, dos Prazeres Rodrigues D, Menezes FG (2002) Escherichia coli isolated from seafood: toxicity and plasmid profiles. Int Microbiol 5: 11-14.

20. Ohno A, Marui A, Castro ES, Reyes AA, Elio-Calvo D, et al. (1997) Enteropathogenic bacteria in the La Paz River of Bolivia. Am J Trop Med Hyg 57: 438-444.
21. McCoy E, Morrison J, Cook V, Johnston J, Eblen D, et al. (2011) Foodborne agents associated with the consumption of aquaculture catfish. J Food Prot 74: 500-516.

22. Pao S, Ettinger MR, Khalid MF, Reid AO, Nerrie BL (2008) Microbial quality of raw aquacultured fish fillets procured from Internet and local retail markets. $J$ Food Prot 71: 1544-1549.

23. Mischke C (2011) Summary of current research on catfish fry pond management. Mississippi Agricultural and Forestry Experiment Station (MAFES) Bulletin 1196

24. NASS (2010) Catfish processing. United States Department of Agriculture.

25. Huang L, Tu SI, Phillips J, Fratamico P (2012) Mathematical modeling of growth of non-O157 Shiga toxin-producing Escherichia coli in raw ground beef. J Food Sci 77: M217-M225.

26. Tamplin ML (2002) Growth of Escherichia coli $\mathrm{O} 157: \mathrm{H} 7$ in raw ground bee stored at 10 degrees $C$ and the influence of competitive bacterial flora, strain variation, and fat level. J Food Prot 65: 1535-1540.

27. Koseki S, Isobe S (2005) Prediction of pathogen growth on iceberg lettuce under real temperature history during distribution from farm to table. Int $\mathrm{J}$ Food Microbiol 104: 239-248.

28. USDA FSIS (2011) Detection and Isolation of non-O157 Shiga-toxin Producing Escherichia coli (STEC) from Meat Products

29. National Advisory Committee on Microbiological Criteria for Foods (2006) Requisite scientific parameters for establishing the equivalence of alternative methods of pasteurization. J Food Prot 69: 1190-1216.

30. Baranyi J, Roberts TA (1994) A dynamic approach to predicting bacteria growth in food. Int J Food Microbiol 23: 277-294. 